\title{
PEMANFAATAN KULIT UBI KAYU MENJADI KERUPUK DAN PENENTUAN KADAR NUTRIENNYA
}

\author{
Yusbarina, Rumondang Bulan Nst, dan Zul Alfian
}

\begin{abstract}
Program Studi Pendidikan Kimia, Fakultas Tarbiyah dan Keguruan, Universitas Islam Negeri Sultan Syarif Kasim, Riau, Indonesia

Program Studi Kimia, FMIPA, Universitas Sumatera Utara, Medan, Indonesia
\end{abstract}

E-mail: yusbarina_7@yahoo.com

\begin{abstract}
ABSTRAK
Industri rumah tangga keripik ubi kayu Sanjai di Medan bahan bakunya 10 ton perhari dan 30\% dari bahan baku tersebut dibuang yaitu kulitnya. Penelitian ini bertujuan untuk mengetahui berapa kadar HCN dalam kulit ubi kayu, bagaimana cara mengolah kulit ubi kayu menjadi kerupuk, berapa kadar nutrien (karbohidrat, protein, lemak, air dan abu), serta hasil uji organoleptik kerupuk. Hasil penelitian menunjukkan kadar HCN kulit ubi kayu: 22,14 mg/kg. Hal ini menunjukkan bahwa kulit ubi kayu aman untuk diolah menjadi bahan makanan. Kerupuk dibuat dengan mengolah kulit ubi kayu dengan tepung tapioka dengan perbandingan 1:2. Kadar karbohidrat, protein, air, abu, dan lemak kerupuk secara berturut -turut yaitu 82,90; 1,10; 13,00; 2,09; dan 0,10\%. Hasil uji organoleptik menunjukkan skala 3 (suka).
\end{abstract}

Kata Kunci: kulit ubi kayu, kerupuk, kadar nutrien

\section{PENDAHULUAN}

Ubi Kayu merupakan salah satu tanaman umbi - umbian, yang dapat dimanfaatkan sebagai sumber karbohidrat yang efisien dan murah. Ubi kayu merupakan komoditas ketiga di Indonesia setelah padi dan jagung. Produksi ubi kayu di Indonesia sebagian besar dimanfaatkan sebagai bahan pangan (64\%), sedangkan sisanya dimanfaatkan sebagai bahan baku industri pati, dan pakan (Soebijanto T, 1993).

Tanaman ubi kayu (Manihot esculanta crantz) banyak dijumpai di Sumatera Utara dengan hasil sangat melimpah. Ubi kayu oleh masyarakat dijadikan bahan baku keripik, di salah satu industri rumah tangga keripik ubi kayu, bahan bakunya mencapai $8-10$ ton perhari dan $60 \%$ dari bahan baku tersebut dibuang. Salah satunya adalah kulitnya. Terbayang berapa ton perhari limbah tersebut terbuang percuma tanpa termanfaatkan, padahal kulit ubi kayu masih bisa dimanfaatkan.

Salah satu pemanfaatan limbah ubi kayu adalah dengan mengolah kulitnya menjadi kerupuk. Pengolahan kulit ubi kayu menjadi kerupuk diperlukan pemeriksaan pendahuluan terhadap kadar HCN yang terdapat pada kulit ubi kayu tersebut. Hal ini disebabkan kadar HCN yang berbeda - beda pada setiap jenis ubi kayu dan akan mempengaruhi rasanya. Ubi kayu dengan kandungan $\mathrm{HCN}$ kurang dari $50 \mathrm{ppm}$ ( $\mathrm{mg} / \mathrm{kg}$ berat bahan basah), umumnya memiliki rasa yang enak (cenderung agak manis) dan tentunya aman untuk dikonsumsi, sementara ubi kayu dengan kandungan $\mathrm{HCN}$ lebih dari 50 ppm ( $\mathrm{mg} / \mathrm{kg}$ berat bahan basah) memiliki rasa pahit dan berbahaya bagi kesehatan. Hasil penelitian para pakar menunjukkan bahwa jenis/varietas ubi kayu gading, adira 1, mangi, betawi, mentega, randu, lanting dan pulut termasuk jenis ubi kayu manis yang dapat dikonsumsi langsung (Rukmana. R, 1997).

Kerupuk adalah salah satu jenis makanan ringan yang banyak disukai oleh masyarakat Indonesia, baik dimakan langsung maupun dimakan dengan nasi sebagai penambah selera makan.

Kadar nutrien (karbohidrat, protein, lemak, air, dan abu) dari bahan makanan sangat penting untuk diketahui. Dimana karbohidrat merupakan sumber kalori utama bagi hampir seluruh penduduk dunia, khususnya bagi penduduk negara yang sedang berkembang. Begitu juga 
dengan protein yang merupakan suatu zat makanan yang amat penting bagi tubuh, karena zat ini disamping berfungsi sebagai bahan bakar dalam tubuh juga berfungsi sebagai zat pembangun dan pengatur. Lemak juga merupakan zat makanan yang penting untuk menjaga kesehatan tubuh manusia. Kadar abu ada hubungannya dengan mineral suatu bahan. Kandungan air sangat berpengaruh terhadap konsistensi bahan pangan, pada umumnya keawetan bahan pangan mempunyai hubungan erat dengan kadar air yang dikandungnya (Winarno, 1980).

Berdasarkan uraian di atas, peneliti tertarik untuk memanfaatkan limbah kulit ubi kayu jenis pulut dari industri rumah tangga keripik ubi kayu dengan cara mengolahnya menjadi kerupuk dan melakukan pemeriksaan pendahuluan terhadap kadar HCN yang terkandung di dalam limbah kulit ubi kayu tersebut, selanjutnya menganalisa kadar nutrien (karbohidrat, protein, lemak, air dan abu) pada kerupuk kulit ubi kayu yang dihasilkan. Serta uji organoleptik kerupuk kulit ubi kayu.

\section{METODOLOGI PENELITIAN}

Alat. Alat-alat yang digunakan pada penelitian ini adalah peralatan gelas, labu Kjeldahl, alat destilasi, neraca analitis (Meller), oven (Memmert), desikator, tanur (Gallen Kamp), alat soklet, peralatan dapur.

Bahan. Bahan yang digunakan pada penelitian ini kulit ubi kayu jenis pulut, akuades, $\mathrm{NaOH}_{(\mathrm{s})} \mathrm{KI}_{(\mathrm{s})}, \mathrm{AgNO}_{3(\mathrm{~s})}$, Selenium $(\mathrm{s}), \mathrm{Na}_{2} \mathrm{SO}_{4(\mathrm{~s})}$, $\mathrm{CuSO}_{4(\mathrm{~s})}, \mathrm{H}_{2} \mathrm{SO}_{4(\mathrm{p})}$, Indikator Fenolftalen, $\mathrm{H}_{3} \mathrm{BO}_{3}$ $3 \%, \mathrm{HCl} 37 \%$, Petroleum eter, bumbu masakan.

Penentuan kadar HCN dalam kulit ubi kayu. Analisa kadar HCN kulit ubi kayu ditentukan dengan metode AOAC (1970). Kulit ubi kayu ditumbuk halus (20 Mesh). Ditimbang 10-20 g sampel yang telah ditumbuk halus tersebut. Ditambah $100 \mathrm{ml}$ aquades dalam labu kjedahl. Dimaserasikan selama 2 jam. Ditambah lagi $100 \mathrm{ml}$ aquades. Didestilasi dengan uap (steam destilation). Distilat ditampung dalam erlenmeyer yang telah diisi dengan $20 \mathrm{ml} \mathrm{NaOH}$ 2,5\%. Setelah destilat mencapai $150 \mathrm{ml}$, destilasi dihentikan. Destilat ditambah $8 \mathrm{ml} \mathrm{NH} \mathrm{NH}_{4} \mathrm{OH}$ dan
$5 \mathrm{ml} \mathrm{KI} 5 \%$ dan dititrasi dengan larutan $\mathrm{AgNO}_{3}$ $0,02 \mathrm{~N}$ sampai terjadi kekeruhan. (kekeruhan ini akan mudah terlihat apabila di bawah erlenmeyer ditaruh kertas karbon hitam).

Pembuatan kerupuk kulit ubi kayu. Kerupuk dibuat dengan perbandingan kulit ubi kayu dengan tepung tapioka yaitu (1:1). Kulit ubi kayu dibersihkan dan dicuci dengan air bersih.Direbus dan dihaluskan bumbu yang terdiri dari: $1 / 2$ sendok teh garam, 10 siung bawang merah dan 5 siung bawang putih yang telah dihaluskan, $1 / 2$ sendok teh soda kue, 1/4 sendok teh merica halus, penyedap disiapkan. Kulit ubi kayu yang telah halus dimasukkan ke dalam bumbu tersebut sambil diaduk perlahan supaya bumbunya tercampur rata. Ditambah tepung tapioka dan diaduk rata. Adonan digulung memanjang, lalu dikukus dalam dandang selama 1 jam. Setelah matang, adonan diangkat dan didiamkan selama satu malam. Selanjutnya gulungan tersebut dipotong tipistipis dan dijemur di bawah sinar matahari hingga kering merata.

Penentuan kadar nutrien kerupuk kulit ubi kayu. Kadar nutrien yang diukur adalah kadar air, kadar abu, kadar protein, kadar lemak, kadar karbohidrat.

Penentuan kadar air kerupuk kulit ubi kayu. Penentuan kadar air kerupuk kulit ubi kayu dilakukan dengan metode pengeringan dalam oven pada suhu $100-105^{\circ} \mathrm{C}$. Ditimbang dengan tepat $1,3455 \mathrm{~g}$ sampel dalam cawan porselin yang telah diketahui beratnya. Kemudian dikeringkan dalam oven pada suhu $100-105^{\circ} \mathrm{C}$ selama sekitar 6 jam. Didinginkan cawan ke dalam desikator selama 20 menit. Setelah dingin ditimbang berat kering. Hal ini diulangi terus sampai diperoleh berat yang konstan, kemudian dihitung kadar airnya.

Penentuan kadar abu kerupuk kulit ubi kayu. Penentuan kadar abu kulit ubi kayu dan kerupuk yang dihasilkan dilakukan dengan metode pembakaran dalam tanur pada suhu $500^{\circ} \mathrm{C}$ hingga diperoleh abu berwarna putih. Ditimbang dengan tepat $2 \mathrm{~g}$ sampel dalam cawan porselin yang telah diketahui beratnya. Diletakkan dalam tanur pengabuan, kemudian dibakar pada suhu $500^{\circ} \mathrm{C}$ hingga diperoleh abu 
berwarna keputih - putihan. Kemudian didinginkan dalam desikator dan ditimbang. Hal ini diulangi terus sampai diperoleh berat yang konstan, kemudian dihitung kadar abunya.

Penentuan kadar protein kerupuk kulit ubi kayu. Analisa kadar protein kulit ubi kayu dan kerupuk yang dihasilkan ditentukan dengan metode Kjedahl. Ditimbang 0,1 g sampel lalu dimasukkan ke dalam tabung reaksi. Ditambahkan Selenium $\left(\mathrm{Na}_{2} \mathrm{SO}_{4}+\mathrm{CuSO}_{4}+\mathrm{Se}\right)$ dan 2,5 $\mathrm{ml} \mathrm{H}_{2} \mathrm{SO}_{4(\mathrm{p})}$. Didestruksi sampel di dalam lemari asam sampai larutan yang ada di dalam tabung reaksi menjadi jernih. Kemudian dipindahkan sampel tersebut ke dalam labu kjedahl lalu ditambahkan $50 \mathrm{ml}$ aquades, 3 tetes Indikator fenolftalein $1 \%$ dan $\mathrm{NaOH} 35 \%$ sampai berwarna merah. Disediakan penampung destilat berupa labu erlenmeyer yang berisi $5 \mathrm{ml}$ $\mathrm{H}_{3} \mathrm{BO}_{3} 3 \%$ dan $15 \mathrm{ml}$ aquades. Dipasang labu kjedahl pada alat destilasi, kemudian diletakkan penampung destilat pada tempatnya, kemudian didestilasi sampai diperoleh $150 \mathrm{ml}$ destilat yang berwarna hijau muda. Dititrasi destilat tersebut dengan $\mathrm{HCl} 0,01150 \mathrm{~N}$ sehinga berwarna merah jambu. Dihitung \% N dan kadar proteinnya.

Penentuan kadar lemak kerupuk kulit ubi kayu. Analisa kadar lemak kulit ubi kayu dan kerupuk yang dihasilkan ditentukan dengan cara ekstraksi kontinu dengan alat soklet. Sebanyak $10 \mathrm{~g}$ sampel dibungkus dengan kertas saring dan dimasukkan ke dalam alat soklet. Ke dalam labu destilasi dimasukkan Petroleum Eter sebanyak $2 / 3$ bagian labu, kemudian sampel tersebut diekstraksi selama beberapa jam sampai ekstrak yang diperoleh tidak lagi berwarna. Ekstrak yang diperoleh dipindahkan ke dalam cawan porselin yang telah diketahui beratnya, kemudian dikeringkan dalam oven pada suhu $80^{\circ} \mathrm{C}$. Didinginkan di desikator dan ditimbang. Dihitung kadar lemaknya.

Penentuan kadar karbohidrat kerupuk kulit ubi kayu. Analisa kadar karbohidrat kerupuk kulit ubi kayu dilakukan dengan cara perhitungan kasar (Proximate analysis). Kadar karbohidrat kulit ubi kayu dan kerupuk yang dihasilkan ditentukan dengan menghitung selisih antara $100 \%$ dengan jumlah persentase kadar air, abu, protein, dan lemak. Kadar Karbohidrat $=$ $100 \%-\%($ protein + lemak + air + abu).

Penentuan Nilai Organoleptik kerupuk kulit ubi kayu. Uji ini meliputi warna, rasa, bau dan tekstur yang ditentukan dengan uji kesukaan oleh 30 orang panelis, dimana para panelis bukan perokok dan sebelum mencicipinya diharuskan minum air putih terlebih dahulu. Uji ini ditentukan dengan skala hedonik sebagai berikut:

\begin{tabular}{ll}
\hline $\begin{array}{l}\text { Uji Kesukaan } \\
\text { (Skala hedonik) }\end{array}$ & Skala Numerik \\
\hline Amat sangat suka & 5 \\
Sangat suka & 4 \\
Suka & 3 \\
Kurang suka & 2 \\
Tidak suka & 1 \\
\hline
\end{tabular}

\section{HASIL DAN PEMBAHASAN}

Kadar HCN dalam kulit ubi kayu.

Glikosida sianogenetik merupakan senyawa yang terdapat dalam bahan makanan nabati dan secara potensial sangat beracun karena dapat terurai dan mengeluarkan hidrogen sianida (HCN). Hidrogen sianida dikeluarkan bila komoditi tersebut dihancurkan, dikunyah, mengalami pengirisan, atau rusak. Bila dicerna, hidrogen sianida sangat cepat terserap oleh alat pencernaan masuk ke dalam saluran darah.

Dari penelitian yang dilakukan maka dapat diketahui bahwa kulit ubi kayu dapat dimanfaatkan menjadi kerupuk. Pengukuran kadar HCN dari kulit ubi kayu yang digunakan menunjukkan angka yang aman untuk dikonsumsi yaitu 22,14 mg/kg (lihat Tabel 1). Menurut Rukmana (1997) Ubi kayu yang aman untuk dikonsumsi ditandai dengan kandungan HCN kurang dari $50 \mathrm{mg} / \mathrm{kg}$ ubi basah.

Kadar HCN yang merupakan faktor anti nutrisi pada kulit ubi kayu dapat dilakukan pengurangan dengan berbagai cara. Proses proses pengolahan kulit ubi kayu menjadi kerupuk seperti perendaman, pengukusan, penjemuran akan mengurangi kadar $\mathrm{HCN}$ yang masih ada di kulit ubi kayu. 
Tabel 1. Hasil Pengukuran Kadar HCN dari Kulit Ubi Kayu.

\begin{tabular}{|l|l|}
\hline Perulangan & Kadar $\mathrm{HCN}(\mathrm{mg} / \mathrm{kg})$ \\
\hline I & 21,60 \\
\hline II & 24,30 \\
\hline III & 21,60 \\
\hline IV & 21,60 \\
\hline V & 21,60 \\
\hline Rata - rata & 22,14 \\
\hline
\end{tabular}

HCN menguap sejalan dengan terjadinya penguapan pada saaat mengukus kemudian penjemuran kerupuk di bawah sinar matahari selama \pm 12 jam juga akan menambah hilangnya HCN seiring dengan berkurangnya kadar air bahan pada saat dijemur.

\section{Pembuatan Kerupuk Kulit Ubi Kayu.}

Kulit ubi kayu yang digunakan adalah lapisan ke dua yang berwarna putih kemerahan (lihat gambar 1). Pada pembuatan keripik ubi kayu, kulit ini dibuang. Tepung yang digunakan adalah tepung tapioka.

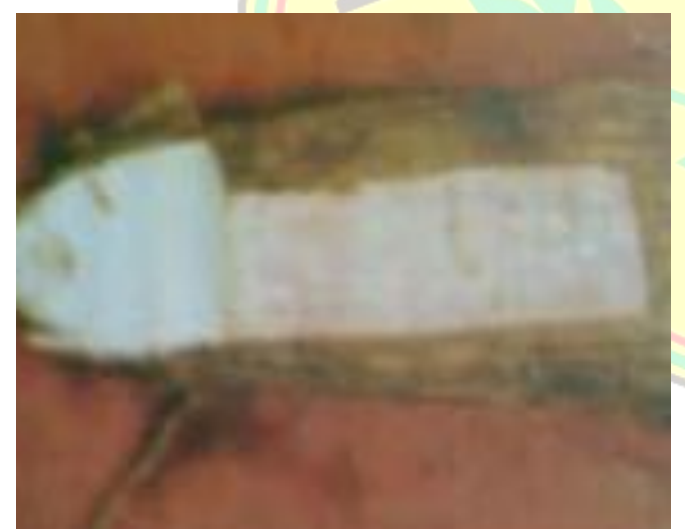

Gambar 1. kulit ubi kayu

Kerupuk dibuat dengan perbandingan kulit ubi kayu dengan tepung tapioka (1:2). Perbandingan ini menghasilkan tekstur yang dapat dibentuk sehingga mudah untuk dipotong. Untuk menambah cita rasa, ditambahkan bumbu - bumbu masakan. Adonan selanjutnya diproses dengan cara pengukusan dan penjemuran di bawah sinar matahari. Penjemuran dilakukan sampai kerupuk kering merata. Setelah itu, kerupuk mentah digoreng dengan miyak goreng panas, sehingga didapat kerupuk kulit ubi kayu yang siap untuk dikonsumsi (lihat gambar 2).

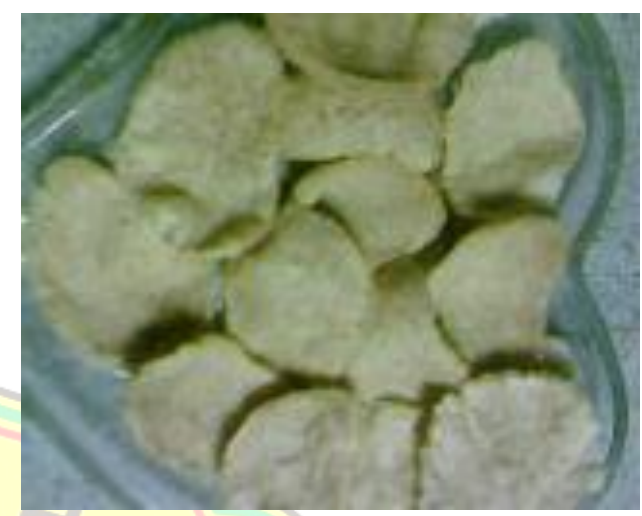

Gambar 2. Kerupuk kulit ubi kayu

Kadar Nutrien Kerupuk Kulit Ubi Kayu.

Pengujian kadar nutrien dari kerupuk kulit ubi kayu dimaksudkan untuk memberi informasi kepada konsumen tentang nilai gizi dari produk makanan yang akan di konsumsi. Selain enak, suatu produk makanan haruslah bergizi.

\section{Kadar Air Kerupuk Kulit Ubi Kayu.}

Kadar air sangat berpengaruh terhadap mutu bahan makanan. Kadar air dalam bahan makanan ikut menentukan kesegaran dan daya tahan bahan makanan tersebut. Kadar air yang tinggi mengakibatkan mudahnya bakteri, kapang, dan khamir untuk berkembang biak, sehingga akan terjadi perubahan pada bahan makanan. Pengurangan kadar air dilakukan dengan cara penguapan dan pengeringan. Pengurangan kadar air selain bertujuan mengawetkan juga mengurangi besar dan berat bahan makanan sehingga memudahkan pengepakan. Pada penelitian ini, adonan yang telah dikukus dan dipotong, dijemur sampai kering untuk mengurangi kadar air dalam kerupuk.

Tabel 2. Hasil Pengukuran Kadar air dari Kerupuk Kulit Ubi Kayu.

\begin{tabular}{|c|c|}
\hline Perulangan & Kadar air (\%) \\
\hline I & 11,00 \\
\hline II & 12,00 \\
\hline III & 16,00 \\
\hline IV & 12,00 \\
\hline V & 14,00 \\
\hline Rata - rata & 13,00 \\
\hline
\end{tabular}

Menurut syarat mutu keripik singkong SNI 01-4305-1996, kadar air maksimal 5\%. Pada 
penelitian ini didapatkan kadar air kerupuk $13 \%$. Hal ini disebabkan kurangnya waktu penjemuran kerupuk sehingga pengeringan kurang sempurna.

\section{Kadar Abu Kerupuk Kulit Ubi Kayu.}

Kadar abu ada hubungannya dengan mineral suatu bahan. Apabila akan ditentukan jumlah mineralnya dalam bentuk aslinya adalah sangat sulit, oleh karenanya biasanya dilakukan dengan menentukan sisa-sisa pembakaran garam mineral tersebut, yang dikenal dengan pengabuan.

Kulit ubi kayu mempunyai serat yang banyak dan kasar sehingga mempunyai kadar abu yang tinggi, sedangkan tepung tapioka telah mengalami proses yang cukup banyak dalam penghalusannya sehingga mempunyai tekstur yang halus dan sedikit serat kasarnya. Kerupuk dibuat dengan perbandingan kulit ubi kayu dengan tepung tapioka (1:2). Komposisi tepung tapioka yang lebih banyak dari kulit ubi kayu mempengaruhi kadar abu kerupuk. Kadar abu kerupuk kulit ubi kayu yaitu 5,07\%.

Tabel 3. Hasil Pengukuran Kadar Abu dari Kerupuk Kulit Ubi Kayu.

\begin{tabular}{|c|c|}
\hline Perulangan & Kadar Abu (\%) \\
\hline I & 2,90 \\
\hline II & 2,91 \\
\hline III & 2,90 \\
\hline IV & 2,91 \\
\hline V & 2,88 \\
\hline Rata - rata & 2,90 \\
\hline
\end{tabular}

Kadar Protein Kerupuk Kulit Ubi Kayu.

Protein merupakan suatu zat makanan yang amat penting bagi tubuh, karena zat ini disamping berfungsi sebagai bahan bakar dalam tubuh juga berfungsi sebagai zat pembangun dan pengatur. Nilai protein kerupuk kulit ubi kayu yaitu $1,10 \%$.

Tabel 4. Hasil Pengukuran Kadar protein dari Kerupuk Kulit Ubi Kayu.

\begin{tabular}{|c|c|}
\hline Perulangan & Kadar protein (\%) \\
\hline I & 1,09 \\
\hline II & 1,10 \\
\hline III & 1,11 \\
\hline
\end{tabular}

\begin{tabular}{|c|c|}
\hline IV & 1,08 \\
\hline V & 1,12 \\
\hline Rata - rata & 1,10 \\
\hline
\end{tabular}

Kadar Lemak Kerupuk Kulit Ubi Kayu.

Lemak juga merupakan zat makanan yang penting untuk menjaga kesehatan tubuh manusia. Nilai lemak kerupuk kulit ubi kayu yaitu $1,10 \%$.

Tabel 4. Hasil Pengukuran Kadar lemak dari Kerupuk Kulit Ubi Kayu.

\begin{tabular}{|c|c|}
\hline Perulangan & Kadar lemak (\%) \\
\hline I & 0,08 \\
\hline II & 0,10 \\
\hline III & 0,12 \\
\hline IV & 0,09 \\
\hline V & 0,11 \\
\hline Rata - rata & 0,10 \\
\hline
\end{tabular}

Kadar Karbohidrat Kerupuk Kulit Ubi Kayu.

Karbohidrat merupakan sumber kalori utama. Penentuan Kadar karbohidrat dilakukan dengan proximate analysis yaitu suatu analisis dimana kandungan karbohidrat termasuk serat kasar diketahui bukan melalui analisis tetapi melalui perhitungan, yaitu:

$\%$ Karbohidrat $=100 \%-\%$ (Protein+Lemak+Abu+Air $)$

Hasil metode ini biasanya ini dicantumkan dalam daftar komposisi makanan.

Tabel 6. Hasil Pengukuran Kadar Karbohidrat dari Kerupuk Kulit Ubi Kayu.

\begin{tabular}{|c|c|}
\hline Perulangan & Kadar karbohidrat (\%) \\
\hline I & 82,89 \\
\hline II & 82,89 \\
\hline III & 82,90 \\
\hline IV & 82,90 \\
\hline V & 82,92 \\
\hline Rata - rata & 82,90 \\
\hline
\end{tabular}

Nilai karbohidrat kerupuk kulit ubi kayu yaitu $82,90 \%$. Tingginya nilai karbohidrat kerupuk berasal dari tepung tapioka yang ditambahkan dalam pembuatannya. Selain itu disebabkan oleh perhitungan yang dipakai adalah perhitungan kasar (proximate analysis) sehingga jumlah kadar ini ditentukan oleh kadar 
lemak, kadar air, kadar abu dan kadar protein dari kerupuk.

\section{Uji Organoleptik Kerupuk Kulit Ubi} Kayu.

Uji organoleptik adalah penilaian penggunaan indera, penilaian menggunakan kemampuan sensorik, tidak dapat diturunkan pada orang lain. Salah satu cara pengujian organoleptik adalah dengan metode uji pencicipan yang disebut juga dengan "Acceptance Tests". Uji pencicipan menyangkut penilaian seseorang akan suatu sifat atau kualitas suatu bahan yang menyebabkan orang menyenangi. Pada uji pencicipan dapat dilakukan menggunakan panelis yang belum berpengalaman. Dalam kelompok uji pencicipan ini termasuk uji kesukaan (hedonik).

Pada uji hedonik, panelis dimintakan tanggapan pribadinya tentang kesukaan atau sebaliknya ketidaksukaan. Di samping panelis mengemukakan tanggapan senang, suka atau kebalikannya, mereka juga mengemukakan tingkat kesukaannya. Tingkat-tingkat kesukaan ini disebut skala hedonik. Dalam penganalisaan, skala hedonik ditransformasi menjadi skala numerik menurut tingkat kesukaan. Dengan data numerik ini dapat dilakukan analisis-analisis statistik.

Tabel 7. Hasil Uji organoleptik kerupuk kulit ubi kayu

\begin{tabular}{|l|c|c|c|c|c|}
\hline Sampel & Warna & Rasa & Bau & Tekstur & $\begin{array}{c}\text { Penerimaan } \\
\text { Keseluruhan }\end{array}$ \\
\hline $\begin{array}{l}\text { Kerupuk } \\
\text { kulit ubi } \\
\text { kayu }\end{array}$ & 3,27 & 3,53 & 3,23 & 3,43 & 3,36 \\
\hline
\end{tabular}

Keterangan: ${ }^{*}$ rata-rata dari 30 panelis

Para panelis yang dipilih haruslah tidak perokok karena perokok memiliki kesensitifan rasa yang kurang. Sebelum mencicipi kerupuk, diharuskan minum air putih terlebih dahulu. Hal ini dimaksudkan agar rasa yang dirasakan benar - benar hanya dari kerupuk.

Warna merupakan parameter pertama yang menentukan tingkat penerimaan konsumen terhadap suatu produk. Penelitian secara subyektif dengan penglihatan sangat menentukan dalam pengujian organoleptik warna. Pengujian organoleptik yang dilakukan pada kerupuk kulit ubi kayu menunjukkan bahwa rata-rata kesukaan panelis terhadap warna kerupuk kulit ubi kayu yang dihasilkan adalah 3,27 (suka). Hal ini menunjukkan kerupuk yang berwarna coklat harus diolah lebih lanjut sehingga didapatkan warna yang lebih menarik.

Rasa dan bau merupakan parameter penting dalam uji organoleptik. Faktor penerimaan konsumen terhadap makanan tergantung pada rasa dan bau makanan tersebut. Pengujian organoleptik yang dilakukan pada kerupuk kulit ubi kayu menunjukkan bahwa rata-rata kesukaan panelis terhadap rasa dan bau kerupuk kulit ubi kayu yang dihasilkan berturut - turut adalah 3,53 (suka) dan 3,23 (suka). Rasa dan bau kerupuk kulit ubi dihasilkan dari bumbu-bumbu masakan yang ditambahkan.

Pengujian organoleptik yang dilakukan pada kerupuk kulit ubi kayu menunjukkan bahwa rata-rata kesukaan panelis terhadap tekstur kerupuk kulit ubi kayu yang dihasilkan adalah 3,43 (suka). Tekstur yang tipis dan garing merupakan faktor utama penyebab panelis menyukai tekstur kerupuk kulit ubi kayu.

Hasil Uji organoleptik terhadap warna, rasa, bau, dan tekstur kerupuk menunjukkan skala 3 untuk penerimaan keseluruhan. Artinya panelis menyukai kerupuk kulit ubi kayu.

\section{KESIMPULAN}

Hasil penelitian menunjukkan kadar $\mathrm{HCN}$ kulit ubi kayu: 22,14 mg/kg. Hal ini menunjukkan bahwa kulit ubi kayu aman untuk diolah menjadi bahan makanan. Kerupuk dibuat dengan mengolah kulit ubi kayu dengan tepung tapioka dengan perbandingan 1:2. Kadar karbohidrat, protein, air, abu, dan lemak kerupuk secara berturut -turut yaitu 82,$90 ; 1,10 ; 13,00$; 2,09; dan 0,10 \%. Hasil uji organoleptik menunjukkan skala 3 (suka).

\section{DAFTAR PUSTAKA}

Cahyono Bambang. 2004. Aneka Produk Olahan Ubi Kayu. Semarang: CV Aneka Ilmu.

Djaafar, T.F. 2003. Ubi Kayu dan Olahannya. Yogyakarta: Kanisius. 
Purwanti Sri. 2005. Pengaruh Perlakuan Terhadap Kadar Asam Sianida (HCN) Kulit Ubi Kayu Sebagai Pakan Alternatif. http://disnaksel.info/index.php. Diakses tanggal 10 Agustus 2007

Rukmana, H.R. 1997. Ubi Kayu Budidaya dan Pascapanen. Yogyakarta: Kanisius.

Sediaoetomo, A. 1986. Ilmu Gizi. Jilid 1. Jakarta: Penerbit Dian Rakyat.

Soekarto, S.T. 1981. Penilaian Organoleptik untuk Industri Pangan dan Hasil Pertanian. Institut Pertanian Bogor. Bogor.
Sudarmadji Slamet. 1989. Analisa Bahan Makanan dan Pertanian. Yogyakarta: Liberty Yogyakarta.

Sudarmadji Slamet. 1984. Prosedur Analisa Untuk Bahan Makanan dan Pertanian. Edisi Ketiga. Yogyakarta: Liberty Yogyakarta.

Winarno, F.G. 1995. Kimia Pangan dan Gizi. Jakarta: PT Gramedia Pustaka Utama.

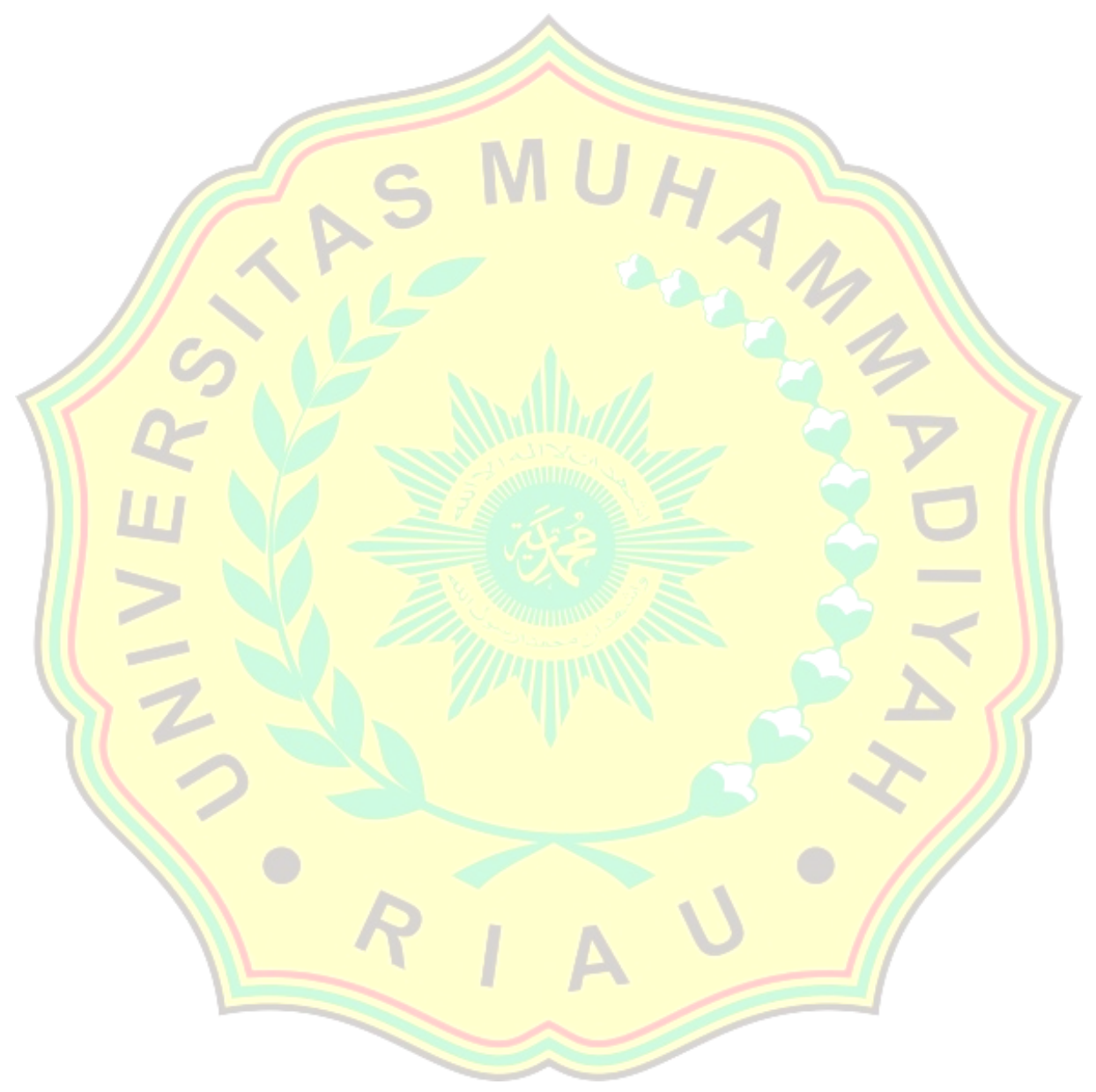

